\title{
Aspiration, Career Progression and Overseas Trained Teachers (OTTs) in England
}

Paul Miller, University of Huddersfield, UK

\begin{abstract}
The recruitment of Overseas Trained Teachers in England is a matter that has received as much attention inside the United Kingdom as outside. Education systems in small island and developing states especially, were believed to have been placed "at risk" following the departure of experienced and qualified teachers. Correspondingly, the presence of overseas trained teachers in England has contributed to, inter alia, workforce stability, behavioural management solutions and curriculum enhancement. Despite these contributions, however, very little is known about the career progression of overseas trained teachers in England. Through a Tracer Study of overseas trained teachers recruited between 2001-2008, in the first phase of teacher migration to the UK, this qualitative study explored the perceived factors that facilitate and/or hinder the progression of Caribbean overseas trained teachers in England. Drawing on postmodernism, critical and social identity theories, this paper examines how institutional racism and discrimination play a part in restricting the promotion and career progression of overseas trained teachers.
\end{abstract}

Keywords: Overseas trained teachers, England, race, progression, promotion 


\section{International migration to the United Kingdom: past and present}

It is well established that international migration has always played a central part in England's nation building. England's economic and demographic interests are usually push factors behind voluntary migration, skilled or otherwise. Migration has also served as a means of social and ideological control, used by the state in deciding who are most desirable for 'admission'. This is commonly manifested in the racial nature of English immigration policies which creates social, cultural and symbolic boundaries (Miller, 2008a). During the 1950s, migrant selection to England was racially motivated, with certain groups of individuals deemed more desirable than others (Grannum, 2002). Another factor used in deciding who gets entry into England is whether it is felt that migrants can add to the country's knowledge profile. This has been the case historically as well as currently. In the 1950s, migrants from the Caribbean, India and Africa were valued for their manual and domestic skills, but were not considered part of the intelligentsia (Bradford \& Kent, 1993). Although the 1962 Commonwealth Immigration Act went some way in restricting the numbers of migrants employed in the UK, this was not for long, as at the turn of the twentieth century and in particular during the industrial revolution, migrants from all over the world were welcomed with open arms. England needed labour in the form of technical skills, and individuals from former colonies, including the Indian subcontinent and the Caribbean, were encouraged to take up such positions - which either could not be filled by locals and/ or which had been vacated by locals. 
In the early 1970s, for the first time in England's history, the selection and admission of migrants was based more on their 'educational skills and resources' rather than purely on their racial backgrounds (Whitaker 1991, p.19). On the surface, this new system appeared to suggest that England's policy towards migrants was both religious and colour-blind. Some commentators called this new thrust of migration from the Caribbean, Africa and Asia 'inclusive', as it represented a balancing of the pattern of migration from America, Canada, Australia and Europe. By the mid-1970s, fewer migrants were arriving in England from developed countries and more from developing countries, in particular from Asia, the Caribbean and Africa (Dustmann et al. 2003). Whitaker described this period of migration based on skills over race as an "historic watershed" (Whitaker 1991, p.19).

Since the mid-1990s, the selection of migrants based on their education and skills, favouring the highly skilled over family-class immigrants and refugees, has intensified. More than half the numbers of migrants admitted throughout the late 1990s were economic-class migrants (Dustmann et al. 2003) - among them were a considerable number of highly skilled professionals, particularly nurses and medical doctors, engineers and teachers. In 2000, of 227,209 migrants and refugees admitted, 23\% (52,000) were admitted as skilled workers (Kirk 2004). Despite England's preference for highly skilled migrants, however, and despite these professionals bringing significant human capital to England's labour force, the non-recognition of their qualifications and experiences are barriers to integration and therefore their progress (Haque et al. 2002; Miller, 2008b). 
Overseas Trained Teachers in England

The opening up of England to migrants based on 'educational skills and resources' (Whitaker 1991, p.19), rather than based on racial backgrounds, is arguably the foundation stone for the recruitment of overseas trained teachers. However, within the last decade, this openness and tolerance has come under increasing political and social scrutiny and debate, and has seen a range of government led-initiatives aimed at curtailing non- EU migration and/or restricting the privileges and freedom of migrants, be they legal, illegal, unskilled, low skilled or highly skilled (Miller, 2008; Achato, et al. 2010). For example, the qualifying period for individuals in 'Employment Related Categories' (overseas trained teachers included) to become eligible for Indefinite Leave to Remain (ILR) was increased from 4-5 years with no recourse provided to those persons already in the United Kingdom (Home Office, 2006). Furthermore, all migrants, including overseas trained teachers, are now required to complete English language and 'Life in the UK' tests as part of the requirements for obtaining Indefinite Leave to Remain in the UK (Home Office, 2006). Additionally, the terms of employment for overseas trained teachers were varied to allow their deportation if, after four years of teaching in the UK, they failed to achieve UK Qualified Teacher Status (Department for Education and Skills, 2007).

An overseas trained teacher is any teacher who has undertaken teacher training outside of the European Economic Area and Switzerland and has been recognised by the competent authority in their home country (DfES, 2007). Overseas trained teachers in England 
come from OECD countries, including the United States and Canada, and from other places such as Asia, Africa and the Caribbean. It is appropriate to make two important points at this juncture. First, as at 01 April 2012, the Department for Education removed the requirement for teachers trained in Canada, the United States, Australia and New Zealand to undergo any additional training leading to the award of UK Qualified Teacher Status (QTS), and as a result they can apply to the National College for Teaching and Leadership (NCTL) for UK Qualified Teacher Status without undertaking further training or assessment in England (DfE, 2014, p.2). Second, overseas trained teachers without UK Qualified Teacher Status, not including those exempt from further training and assessment are considered "Unqualified teachers" until they have satisfactorily completed UK-based qualifying training and assessment.

The cultural backgrounds of overseas trained teachers differ considerably. Data on overseas trained teachers is, however, very patchy (McNamara et al, 2004; Morgan et al. 2005; Miller, 2006), prompting then Schools Minister, David Miliband, to conclude that "Information on numbers of teachers with overseas qualifications is not available" (Hansard, 2003). Using Home Office and from Work Permits UK data, Miller (2007) estimated that about 43,000 overseas trained teachers were in the UK (which was approximately $10 \%$ of the total teaching force). Top supplying countries during the period 2001-2005 were South Africa, Australia, United States, New Zealand, Canada and Jamaica. In 2008, the numbers of teachers trained in the Caribbean working in the UK was estimated at just under 4,000. In 2016, the picture had not changed very much in relation to availability of data and top sending countries. Both the Home Office and the 
Department for Education confirmed (email communication with this author), that they no longer collect nationality data on overseas trained teachers and work permit data is no longer broken down into categories (e.g.: teacher, instructors). Nevertheless, from what we know based on recent recruitment activities, top supplying countries are the Irish Republic, Australia, Canada, New Zealand, South Africa and Jamaica (Boffey, 2015). The precise numbers of overseas trained teachers in the UK in 2016 was, however, not known, although one can assume the numbers were fewer than those of the early 2000s, due to the expansion of the European Union (between 2004- 2008) and the mutual recognition of qualification for European Union member states under the Bologna Convention.

The second wave of teacher migration arguably started in 2014 , and is currently ongoing. This paper examines issues to do with the promotion and career progression of overseas trained teachers trained in the Caribbean who arrived in England between 2001-2008 (during the first wave of teacher migration to the UK. I assert that, although migration based on racial background was curtailed in the 1970s in favour of migration based on educational skills and resources, overseas trained teachers in England, from the Caribbean, are faced with adverse promotion and progression prospects based upon racial/ ethnic discrimination. 


\section{Social Identity Theory}

Social Identity Theory suggests that a person's sense of who they are is based on their group membership(s), for example: ethnicity, social class, religious group. Tajfel and Turner (1986) proposed that the groups to which people belong are very important to their social identity and provides a sense of belonging. They also proposed that, in order to enhance one's sense of self, we enhance the status of the group to which we belong (an in-group); for example "English trained teachers make better school leaders" or by discriminating against or having prejudiced views against others (an out-group); for example, "Overseas trained teachers from non-industrialised countries are not as effective as those from industrialised countries". The process of dividing people into an in-group (us) and an out-group (them), called social categorisation, is one of three mental processes, according to Tajfel and Turner (1979) that underpin an 'us' against 'them' mentality. In social categorisation, categories are made in order to help people understand their social environment; for example: Blacks, White, qualified teacher, unqualified teacher. In social identification, people adopt the identity of the group they categorise themselves as belonging to and conform to the norms of the group, which in turn produces an emotional significance to their identification with that group. Furthermore, their self-esteem will become bound up with group membership (McLeod, 2008). In social comparison, people tend to draw comparisons between different groups based on a range of explicit and/or implicit factors. For Tajfel and Turner, understanding these processes is crucial to understanding how prejudice works, since categorising people into 
groups can lead to the exaggeration of differences between groups and similarities of things in the same group (Tajfel and Turner, 1986).

\section{The context of teacher progression in England}

Teacher progression (a process of moving from a particular post or grade to a higher post or grade within one's career) is highly subjective, and often teachers, school boards and policy makers have differing views regarding possible factors influencing appointment decisions. Pioneering research on principal selection in the UK by Morgan et al. (1983) found that their selection was arbitrary and problematic and selection panels were not always clear about the criteria for selection. Furthermore, where criteria did exist, final decisions were not always based upon these. In 2002, Earley et al. found that race/ ethnicity was a problem in teacher progression, as evidenced by the few numbers of Black, Asian and Minority Ethnic (BAME) staff in senior leadership roles in schools. Ten

years later, in 2012, Earley et al. re-confirmed that Black, Asian and minority ethnic staff struggled to gain senior leadership roles in schools due to mainly to stereotypes about their race/ ethnicity.

These observations were confirmed by Bush et al (2006), and Lumby and Coleman (2007; 2017), who also found that race/ethnicity was a factor in the career progression of some black, Asian and minority ethnic teachers. Coleman (2007) also noted that the appointment of women principals is still problematic, commenting that "overall, women are more likely to become head teachers and are now less likely to be categorised into 
pastoral roles, but in some cases women still meet prejudice from governors and others in the wider community" (p. 389). Moreau et al. (2007) and Bullock (2009) showed that women were also disproportionately represented in senior leadership posts.

Shah and Shaikh (2010) found that religious and ethnic affiliation has a major contributing role in teacher progression. Specifically, they found that being male and Muslim was problematic in the quest for a principal job. More generally, research on teacher progression in England identified several barriers associated with teachers gaining a leadership role. These include marginalisation and indirect racism (Powney, 2003) and the subtle influence of informal networks which excludes some groups (Harris, 2003). McNamara et al. (2009) found, inter alia: Black, Asian and minority ethnic teachers are committed to teaching and aspire to progress in their careers although discrimination at work remained a key barrier to progression. Instead of looking at barriers to progression, Miller examined factors that are likely to enable progression. Noting that some factors identified were both barriers and enablers, Miller (2014) found government policy, social connections, and school level jockeying/interference are primary barriers (and simultaneous determinants) to promotion, progression among teachers. Furthermore, Miller (2016) proposed that "White sanction", or being endorsed or supported by a White colleague increases the possibility of access for a Black, Asian and minority ethic teachers. 


\section{The study}

Data collection for this qualitative exploratory study was conducted in two phases. Phase One was conducted between May and November 2015, and included six participants: four males and two females. Phase Two was conducted between February and May 2016, and also included six participants: three males and three females. Participants were from secondary high schools in five London boroughs and held such roles as, teacher and head of department. A combination of convenience and snowball sampling was used to enlist participants. All participants were asked the same questions, the main six questions being: "What factors do you think contribute to or hinder your career progression?"; "What factors do you think are responsible for promotion, progression among teachers?"; "Do you think overseas trained teachers face particular challenges to promotion, progression?"; "Do you think overseas trained teachers from the Caribbean face/ experience particular challenges to their promotion, progression?"; "What do you think can you do to improve your chances of promotion, progression?"; and "What do you think the system can do to improve your chances of promotion/progression?" 


\section{Results}

Table 1: Profile of Phase One participants

\begin{tabular}{|c|c|c|c|c|c|c|c|c|c|c|c|c|}
\hline & 离 & $\underset{<}{\infty}$ & 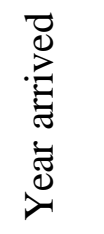 & $\begin{array}{l}\qquad \\
\text { J } \\
\Xi \\
\Xi \\
\Xi\end{array}$ & 光 & 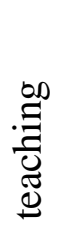 & $\begin{array}{l}\frac{n}{8} \\
0 \\
\frac{0}{0} \\
\tilde{n}\end{array}$ & 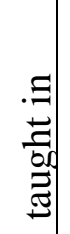 & 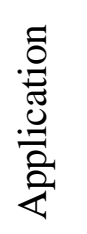 & $\underset{\infty}{\stackrel{0}{0}}$ & 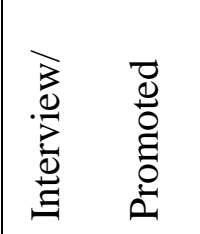 & $\begin{array}{ll}\stackrel{0}{0} \\
\stackrel{0}{0} \\
0 \\
0 \\
0\end{array}$ \\
\hline P1 & Male & $50-59$ & 2005 & & 11 & & 3 & & 2 & & No/ No. & Teacher \\
\hline P2 & Female & $30-39$ & 2007 & & 8 & & 1 & & 1 & & No/ No. & Teacher \\
\hline P3 & Male & $40-49$ & 2008 & & 7 & & 1 & & 3 & & One/ No. & Teacher \\
\hline P4 & Female & $40-49$ & 2003 & & 13 & & 5 & & 3 & & $\begin{array}{l}\text { Three/ } \\
\text { Yes. }\end{array}$ & $\begin{array}{l}\text { Hed of } \\
\text { Department }\end{array}$ \\
\hline P5 & Male & $50-59$ & 2001 & & 15 & & 1 & & 1 & & Yes/ No. & Teacher \\
\hline P6 & Male & 30-39 & 2001 & & 15 & & 3 & & 10 & & Three/Yes. & $\begin{array}{l}\text { Head of } \\
\text { Department }\end{array}$ \\
\hline
\end{tabular}

Between them, the six teachers in Phase One had 69 years of UK teaching experience or an average of 11.5 years (Table 1). Between them, they had taught in 13 schools, with the one teacher having taught in five schools over 13 years. Between them, they had submitted 20 applications for promotion, both internally and externally, with one teacher having made 10 applications. Of the six teachers, with 20 applications between them, four had received an interview and two had been promoted to head of department. 
Table 2: Profile of Phase Two participants

\begin{tabular}{|c|c|c|c|c|c|c|c|c|c|c|c|c|}
\hline & $\begin{array}{l}\overline{0} \\
\overline{0} \\
0\end{array}$ & $\underset{8}{8}$ & $\underset{\nabla}{\Xi}$ & 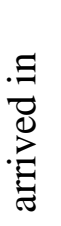 & 光 & 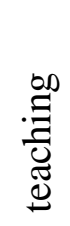 & $\begin{array}{l}\frac{a}{0} \\
0 \\
\frac{0}{0} \\
n\end{array}$ & 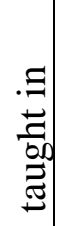 & 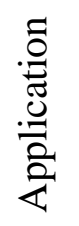 & $\underset{\infty}{\overrightarrow{0}}$ & 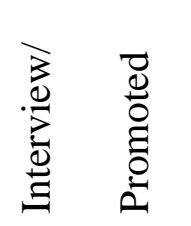 & $\begin{array}{l}\stackrel{0}{\stackrel{0}{0}} \\
\stackrel{0}{0} \\
\stackrel{0}{0}\end{array}$ \\
\hline P1 & Female & $50-59$ & 2003 & & 13 & & 4 & & 2 & & Two/ Yes. & $\begin{array}{l}\text { Head od } \\
\text { department }\end{array}$ \\
\hline $\mathrm{P} 2$ & Female & $30-39$ & 2003 & & 13 & & 2 & & 3 & & No/ No. & Teacher \\
\hline P3 & Male & $40-49$ & 2006 & & 9 & & 1 & & 3 & & One/ No. & Teacher \\
\hline P4 & Female & $40-49$ & 2005 & & 11 & & 2 & & 4 & & No/ No. & Teacher \\
\hline P5 & Male & $50-59$ & 2007 & & 7 & & 1 & & 1 & & No/ No. & Teacher \\
\hline P6 & Male & $30-39$ & 2007 & & 7 & & 2 & & 1 & & No/ No. & Teacher \\
\hline
\end{tabular}

Between them, the six teachers in Phase Two had 60 years of UK teaching experience or an average of 10 years. Between them, they had taught in 12 schools, with the one teacher having taught in four schools over 13 years (Table 2). Between them, they had submitted 14 applications for promotion, both internally and externally, with one teacher making four applications and two teachers making two applications. Of the six teachers, with 14 applications between them, two had received an interview and one had been promoted to head of department.

\section{"What factors do you think contribute to or hinder your career progression?"}

These overseas trained teachers provided several factors which they believe hinder their career progression. Whereas all overseas trained teachers admit to aspiring to gaining a 
promoted post, the reasons they provided for lack of career progression were mixed, and ranged from feelings of "not fitting in" to self-doubt, arising from knock-backs and putdowns experienced within the system. At least two suggested that "I don't think it was the right time for me". Two also suggested that, based on feedback provided after interviews, they "lacked whole school experience". This, they argued, presented them with a catch-22 situation because without opportunities to gain or demonstrate wholeschool experience, their chances of progression would be stunted. One teacher suggested that "lack of self-belief brought about by the system" was a factor in his progression. That is, being told by line managers he was "not quite ready yet" or in interview feedback, "you are so close", had served only to deflate and demoralise him. This, he felt, had nothing to do with his ability, but with who gets promoted, when and to what posts. Two teachers suggested that they were not invited for promotions interviews because "my face did not fit" (suggesting that they are non-White or not part of an in-group). Six teachers, however, attributed their lack of career progression (whether by not getting an interview or getting an interview but not getting a promotion) to racial inequality and discrimination.

\section{"What factors do you think are responsible for promotion, progression among teachers?"}

These overseas trained teachers proposed a range of factors that they felt influenced the promotion and progression of teachers. Their insights were important since, in the previous question they were asked what factors prevented them for getting interviewed/ promoted, whereas this question asked about the factors they believed enabled other teachers. 
One teacher suggested that "If you are known and liked by senior management" there is a greater likelihood of being promoted where there are internal vacancies. Another suggested that "experience and in-depth knowledge of your subject area" was a significant factor. Notwithstanding, in the main, these overseas trained teachers argued that "being White" or "being liked" by persons at school in "positions of influence" contribute to a teacher getting an interview or a promotion. They all felt that applying for an internal promotion was more likely to be successful when "you look and speak like them" and "when you socialise with them outside school".

\section{"Do you think overseas trained teachers face particular challenges to promotion, progression?"}

This question elicited similar responses from all 12 participants, who answered 'yes' suggesting that being an overseas trained teacher has a negative influence on their promotion, progression prospects. One said:

I think that, despite being allowed to migrate here to teach, and, despite having the relevant qualifications and experience, my experience has taught me that school aims to subtly promote British teachers to positions of responsibility and leadership. (Female, Phase 1).

Another one said that:

More recently, there has been a demand for recruiting teachers who attended top UK universities. These are the persons who will be fast-tracked to leadership - not us; not teachers from overseas. (Female, Phase 1.)

And another added: 
A lot of people do not understand us, our culture, and they want us to fit into their system. If we try to retain our teaching personality from back home, this is going to lead to clashes and we are not going to get anywhere. Overseas trained teachers tend to have more experience and a lot more paper qualifications than the average British trained teacher, but we do not get promoted in proportionate terms. (Female, Phase 1).

\section{"Do you think overseas trained teachers from the Caribbean face/ experience particular challenges to their promotion, progression?"}

This question elicited similar responses from all 12 participants who answered 'yes' suggesting that that not only does being an overseas trained teacher put them at a disadvantage in promotion/ progression decisions, but that this disadvantage is compounded by the fact they originate from the Caribbean. One said:

I think that an overseas trained teacher from the Caribbean serves three purposes in England: (a) filling a gap; (b_managing behaviour because of common cultural and language understanding; and (c) obeying instructions. Our ideas that can be implemented for improving teaching and learning are not appreciated, yet, when a counterpart from Canada, the US, South Africa, New Zealand or Australia proposes similar ideas, they are thought of as being genius and these people are promoted. (Female, Phase 1).

Another said:

From my personal experience, in schools where I have worked, I have seen where overseas trained teachers were overlooked for promotion, especially posts internally 
advertised. I often ask myself what the barriers are, and I have narrowed it down to either skin colour, accent or the country your are from. (Female, Phase 2).

Another one also argue:,

There are some underlying factors that prevent overseas trained teachers in general from getting promotion to senior leadership roles - especially in certain key areas within school. The reasons may be lack of confidence in the abilities of overseas trained teachers. No matter how good you are, once they realise you are an overseas trained teacher, they assume you cannot understand the system - no matter how long you have been here. For a person from the Caribbean, this is much worse. From what I observe, it appears as though teachers trained in the Caribbean are good enough only for teaching, for keeping pupils on track, for marking, but not for strategic roles. (Male, Phase1).

\section{"What do you think you can do to improve your chances of promotion,}

\section{progression?"}

Overseas trained teachers want to progress in England's educational system and in their careers. A range of activities, including additional training and leadership of whole school programmes or initiatives, were suggested as possible things they could or would do to increase their chances of promotion/ progression.

One teacher said:

"I am doing a National Professional Qualification for Middle Leadership (NPQML) course as required for a Middle or Senior level course". (Female, Phase 1).

Another said: 
"Seek out opportunities to lead on more departmental / whole school activities". (Male, Phase 1).

Furthermore, another said:

"Prepare better, including finding a mentor...someone liked by the Senior Leadership Team (SLT)”. (Male, Phase 2).

"Seek opportunities to progress, as promotion is not going to come knocking at your door based on years of experience or qualifications held". (Female, phase 1).

However, not all overseas trained teachers were as positive. Showing signs of frustration, one commented that:

"I wish I knew the answer. Although my native language is English, and since I cannot change my skin colour, I guess I should commit to speaking the Queen's English - and that may give me an edge". (Female, Phase 1).

Expressing signs of resignation, another one said:

"I am not sure. To be honest, I have done all I can do". (Male, Phase 1).

Although on the basis of their experiences, overseas trained teachers are skeptical things would change anytime soon, in particular as it pertains to promotion/ progression processes. They were focused on "not giving up" and being "determined to prove" they could be a school leader in the English school system. 


\section{"What do you think the system can do to improve your chances of promotion/progression?"}

These overseas trained teachers had several suggestions as to how they felt schools, in particular, and the educational system as a whole could help them improve their chances of promotion/ progression. One suggested:

"Stop giving overseas trained teachers repetitive and mundane tasks. Give us responsible tasks and monitor progress". (Male, Phase 1).

Another suggested that:

“Offer secondment opportunities to internal candidates should vacancies not be filled externally, as internal candidates would have a better understanding of the school's systems and prove less a burden and challenge to train”. (Female, Phase 1).

Another also suggested that:

"Encourage and support overseas trained teachers to apply for positions and do not only support particular groups of teachers". (Female, Phase 2).

Some suggested that the system as a whole could provide "more training and development opportunities" if school leaders feel overseas trained teachers are lacking particular skills. Furthermore, they also suggested that being given "better feedback" could assist them in improving. They also suggested that school leaders or those in authority could "level the playing field" and "make the promotions process less stressful and more transparent".

At the school level, one teacher reflected that: 
"I have been in my school now for 12 years and I have seen a number of White teachers progressing and, in a sense, leaving me behind. I love my job and I love my school. However, despite applying for internal promotion four times, I have not gotten through. It's always, 'you are not ready yet'. If I am not ready after 12 years in one school working in several roles and amassing significant experience, when will I be ready? I guess when they tell me I am". (Female, Phase 1).

And at the system level, another teacher reflected that:

"More recently, I was invited to attend a course called "Stepping up to Leadership" for Black and minority ethnic teachers. Why can't Black, Asian and minority ethnic teachers not apply to the "Future Leaders" programme like anyone else? Why must there be a course especially for Black, Asian and minority ethnic teachers? Will this solve the problem and create more opportunities? The under-representation of Black, Asian and minority ethnic teachers in schools and in leadership roles is clearly a nationwide issue". (Female, Phase 2).

These overseas trained teachers also suggested that being "stereotyped", "lack of encouragement" and "not having a successful overseas trained teacher role model" were additional school level factors that hampered their chances of promotion/ progression.

\section{Discussion}

Overseas trained teachers play an important role in the stability of England's teaching workforce. And, although current precise numbers are not known, using earlier figures, one might expect that there are no fewer than 43,000 overseas trained teachers in 
England. In 2008, the numbers of overseas trained teachers from the Caribbean in England stood at just under 4,000 - a number which has certainly increased, not least because between September 2015 and January 2016, when 200 new (mostly STEM) teachers arrived from Jamaica. Patchy data aside, however, the evidence presented shows that promotion/ progression among overseas trained teachers from the Caribbean is fraught and problematic, underpinned largely by race/ethnic discrimination and essentialist stereotyping. I propose three discussion points below:

\section{Lack of Opportunities, Support and Encouragement}

There was a strong view among these overseas trained teachers that they were not taken seriously. In part, this view mirrors research by McNamara et al. (2009) on the career aspirations of Black, Asian and minority ethnic teachers in England. Overseas trained teachers in this study described "not being asked to get involved" or being asked to get involved with "low level tasks" that are "repetitive and mundane". Although it can be argued that someone has to do the "repetitive and mundane tasks", overseas trained teachers suggest that they were pigeonholed into certain roles or into taking on certain tasks that did not involve much "responsibility" and therefore offered little or no opportunity for them to use and/or develop leadership skills. Such a situation is contrary to UK public policy, which promotes community cohesion and social justice. Targeted support for the integration and development of overseas trained teachers, that involves internal and external stakeholders, was previously identified by Miller (2008a) as a vital, but missing, element in them being able to thrive in the UK. With appropriate support, 
the investment made by schools in employing overseas trained teachers can be realised. Simultaneously, with support, the investments decision made by overseas trained teachers to teach in England can also be realised. For talent management to be effective and in order for it to realise its potential, it ought to be based only on a single factor, talent; and not on skin colour or country of origin.

Overseas trained teachers also want opportunities to engage in mentoring and secondment activities. There was a strong sense among them that mentoring could offer them a confidential space to speak and for someone to listen to them and help them plan strategies towards future promotion/ progression attempts. Not only would mentoring give the appearance of providing them with empathy, and of taking their aspirations seriously, it could provide them with access to networks not previously accessed or accessible. Whereas Miller (2014) found that networks were used to enable or deny access; Harris (2003) found networks tended to exclude some teachers, including Black, Asian and minority ethnic teachers. Secondments were seen as opportunities that could potentially offer new and different insights, and skills which they could draw upon in completing their next job application or interview. These overseas trained teachers also suggested that secondments could provide "escape opportunities"; that is, being able to temporarily separate from a school or a school system they did not feel valued their skills and talents. The degree of frustration expressed by the overseas trained teachers who participated in this study is consistent with other non-White migrants who also experience downward professional mobility due to challenges of labour market absorption (Haque et al. 2002). 
Good enough to teach, but not to lead

Although possessing over 120 years UK teaching experience between them; and although making over 34 applications for a promoted post between them, the promotion/ progression of overseas trained teachers from the Caribbean who participated in this study appeared to have flatlined. That is, of 12 overseas trained teachers interviewed, only three had been promoted, suggesting that the career progression of the remaining nine had remained static. The flatlining of the promotion/ progression trajectory and therefore the career aspirations of overseas trained teachers is inconsistent with social justice practices in teaching and school leadership, and is problematic for teachers who migrate to the UK, who in good faith, believe, that in a country with strong democratic values, equality of opportunity and access would prevail against colonialist tendencies.

Of 12 overseas trained teachers in this study, only three had been promoted; and those three had been promoted to head of department, not senior leadership roles. I therefore assert that overseas trained teachers in England, from the Caribbean, experience 'occupational confinement'. That is, teachers from the Caribbean have been confined to particular, largely, operational roles, described by some as "repetitive" and "mundane" which provide only limited or no opportunity for capacity-building and growth. These findings underscore findings from Earley et al. (2002) that the glass-ceiling was contributing to Black, Asian and minority ethnic teachers not gaining promotion to leadership roles in English schools. Furthermore, Earley et al. (2012) also lamented the fact that essentialist stereotyping was having a negative impact on the career aspirations 
of Black, Asian and minority ethnic teachers. In the words of one teacher in this study, "to them we are good enough to teach and manage behaviour, but not to lead". That overseas trained teachers are experiencing occupational confinement is problematic, and suggests that urgent work needs to be done by principals, school governors, the Department for Education, teacher recruitment agencies, and all those involved in the recruitment and development of overseas trained teachers to assure them that England operates an egalitarian education system in which capital from anyone from anywhere counts equally and that there is no knowledge hierarchy. Overseas trained teachers were resolute that they needed opportunities to steer the ship and not only opportunities to man the ship.

\section{Race and origin matters in promotion/ progression}

The research findings points to an overwhelming view among overseas trained teachers that, in promotion/ progression activities, being an overseas trained teachers counts against them, and being an overseas trained teacher from the Caribbean counts against them doubly. First, being an overseas trained teacher means being one of 'them' and not one of 'us' (Tajfel \& Turner, 1979). At the heart of this view lies a deficit model of difference that gives automatic equivalency and recognition of status to teachers from European Economic Area (EEA) and Organisation for Economic Co-operation and Development (OCED) countries, although not to teachers from elsewhere. Second, being an overseas trained teacher from a developing country means having considerably less influence in important national level decision-making in the UK, and as a result, although 
teachers from developing countries are allowed to come to England to teach, they are more likely to occupy operational roles. Such a situation highlights two important interconnected imbalances. First, there is a hierarchy of knowledge - and whose knowledge gets validated depends on who is doing the validating. Second, since the acceptance of knowledge is a political activity, countries with only limited influence on the world stage may find it harder for their citizens to gain recognition and acceptance in some jurisdictions.

That overseas trained teachers experience adverse promotion/ progression due to racial discrimination and country of origin is significant. The problem of adverse promotion/ progression due to race and origin in the UK is well documented. Haque et al. (2002) found that highly skilled Black, Asian and minority ethnic migrants- in particular those from the Indian sub-continent, experienced downward professional mobility after arriving in the UK. The double negative effect of being migrant, coupled with being a migrant from a developing country, is therefore a particular challenge to England's publicly stated democratic and social inclusion agendas. Nevertheless, the precise relationship between teacher origin and teacher progression is not one that can be resolved here. However, from what we know about Black, Asian and minority ethnic teachers in England, which includes overseas trained teachers, we know that race matters in promotion/ progression. 


\section{Conclusions}

Overseas trained teachers are crucial to the sustainability and, therefore, the delivery of schooling in England. Although, their precise numbers are not known, they fill a gap due to local teacher shortage and, in doing so, they keep schools afloat. Despite this, they are not the being picked for leadership roles and their responsibilities are usually confined to behaviour management and classroom teaching. They suffer occupational confinement. A significant factor in recruitment of overseas trained teachers from the Caribbean was the suggestion that they would be good at managing poor classroom behaviour and provide failing pupils, especially those of Caribbean heritage, with successful role models. In this study, nine out of 12 teachers had never been promoted, suggesting that their careers had been flatlined, the result of being confined to roles primarily associated with teaching and behaviour management. Three had been promoted, and their progression appear to have peaked at the level of head of department, suggesting some form of ceiling. As the teachers themselves have suggested, they appear to be good enough to teach and manage poor behaviou,r but not good enough to lead.

Overseas trained teachers want opportunities to demonstrate leadership and to contribute to school leadership. Having their career flatlined is not good for them, and it is not good for the schools in which they teach and the education system as a whole. Frustrated teachers means unproductive, sceptical and distracted teachers. And frustrated teachers will not give of their best to their students, school or society as a whole. For things to change for overseas trained teachers, however, in terms of promotion/ progression, they 
need internal and external opportunities, such as shadowing and secondments (temporary reassignment in another school or another job role in an education related agency), support and encouragement from those in charge of their career planning and professional development. They also need mentors who understand their passion and the barriers to progression that they face, and who will work with and for them in confronting and navigating these barriers. For teachers from European Economic Area and Organisation for Economic Co-operation and Development countries, promotion/ progression is much more likely in England's education and political systems that appear to place a higher value on qualifications, skills and experience gained in those, White industrialised countries, than elsewhere. In such systems, the interest of the dominant group is sustained (Krahn et al. 2000). Nevertheless, overseas trained teachers are showing signs of resistance through a counter-narrative that challenges leadership practices and suggest ways in which targeted intervention can be used to support them and provide them with opportunities for promotion/ progression. This counter-narrative of resistance is also predicated on the need overseas trained teachers have for their aspirations to be realised and their ambitions acknowledged. Until significant change is achieved, however, led by policy makers and school leaders, overseas trained teachers from the Caribbean are caught in an essentialist situation, where race discrimination and stereotyping based on their country of origin or initial teacher training, coupled with what UK school leaders and line managers believe they are 'better at' (teaching, behaviour management), will continue to dictate their promotion/ progression, and not their experiences, skills and qualifications. 


\section{References}

Achato, L., Eaton, M., \& Jones, C. (2010). The Migrant Journey. Home Office. Research

Report 43. Available at: www.homeoffice.gov.uk/publications/science-research-

$\underline{\text { statistics/research-statistics/immigration-asylum-research/horr43/ [Accessed } 26 \text { June }}$

2016]

Basran, G., \& Zong, L. (1998). Devaluation of foreign credentials as perceived by visible minority professional immigrants, Canadian Ethnic Studies 30 (3) pp. 6-18.

Boffey, D. (2015). Dozens of Jamaican teachers hired to work in British schools.

Available at: http://www.theguardian.com/education/2015/oct/11/agency-hires-jamaicanteachers-for-english-schools [Accessed 26 June 2016]

Bradford, M., \& Kent, A (1993). Understanding human geography. Oxford: Oxford University Press.

Bullock, K. (2009).The impact of school leadership on pupil outcomes. Research Report DCSF-RR108. London: Department for Children, Schools and Families (DCSF).

Bush, T., Glover, D., \& Sood, K. (2006). Black and minority ethnic leaders in England: A portrait. School Leadership \& Management, 26(3), pp. 289-305.

Coleman, M. (2007). Gender and educational leadership in England: A comparison of Secondary head teachers' views over time. School Leadership \& Management, 27(4), pp. $383-399$. 
Department for Education and Skills (2007). Private email received with definitions of OTTs and related links with varying definitions.

http://www.opsi.gov.uk/si/si2003/20031663.htm .

DfE (2014) School Workforce in England: November 2014, SFR 21/2015, London:

Department of Education. Available at: https://www.gov.uk/government/statistics/schoolworkforce-in-england-november-2014 . [Accessed 11/06/2016]

Dustmann, C., F. Fabbri, \& I. Preston (2003). The local labour market effects of immigration in the UK, HMSO. http://www.homeoffice.gov.uk/rds/pdfs2/rdsolr0603.pdf

Earley, P., Evans, J., Collarbone, P., Gold, A., \& Halpin, D. (2002). Establishing the current state of school leadership in England. Department for Education \& Skills research report RR336. London: HMSO.

Earley, P., Higham, R., Allen, R., Allen, T., Howson, J., Nelson, R., \& Sims, D. (2012).

Review of the school leadership landscape. Nottingham, UK: National College for School Leadership.

Grannum, G. 2002. Tracing your west Indian ancestors. National Archives: England.

Haque, R., Dustmann, C., Fabbri, F., Preston, I., Wadsworth, J., Shields, M., Wheatley Price, S., \& Kempton, J. (2002). Migrants in the UK: their characteristics and labour market outcomes and impacts. London: Home Office.

Harris, A., Muijs, D., \& Crawford, M. (2003). Deputy and assistant heads: Building leadership potential. Nottingham, UK: NCSL 
Kirk, R. (2004). Skills audit of refugees: Home office online report.

http://www.homeoffice.gov.uk/rds/ pdfs04/rdsolr3704.pdf.

Krahn, H., Derwing, T., Mulder, M. \& Wilkinson, L. (2000). Educated and underemployed: Refugee integration into the Canadian labour market, Journal of International Migration and Integration 11: pp. 59-84.

Lumby, J. \& Coleman, M. (2017) Leading for Equality: Making Schools Fairer, London: Sage

Lumby, J., \& Coleman, M. (2007). Leadership and diversity: Challenging theory and practice in Education. London: Sage.

McLeod, S (2008). Social Identity Theory, Available at: http://www.simplypsychology.org/social-identity-theory.html [Accessed 11/06/2016] McNamara, O., Howson, J., Gunter, H., \& Fryers, A. (2009) The leadership aspirations and careers of black and minority ethnic teachers, London: NASUWT/NCSL.

Miller, P. (2016), 'White sanction', institutional, group and individual interaction in the promotion and progression of black and minority ethnic academics and teachers in England, Power \& Education, 8 (3), pp. 205- 221.

Miller, P (2014) Becoming a Principal: Exploring Perceived Discriminatory Practices in the Appointment and Selection of Principals in Jamaica and England. In, K. Beycioglu \& P. Pashiardis (Eds) Multidimensional Perspectives on Principal Leadership Effectiveness, IGI Global 
Miller, P.W (2008a) Overseas trained teachers in England: towards a policy framework for professional and social integration, Policy Futures in Education, 6 (3), pp. 280-285. Miller, P.W (2008b) Downgrading and discounting the qualifications of migrant professionals in England: The case of overseas trained teachers, Education, Knowledge and Economy, (2) 1, pp. 1-12

Miller, P.W (2007). 'Brain gain' in England: How overseas trained teachers have enriched and sustained English education, Perspectives in Education, 25 (2), pp. 25-34. Special Issue on Teacher Migration.

Miller, P.W (2006). Professional Lives in Transition: Overseas trained teachers in England, Caribbean Journal of Education, 28 (2), pp. 187-215

Moreau, M. P., Osgood, J., \& Halsall, A. (2007). Making sense of the glass ceiling in schools: An exploration of women teachers' discourses, Gender and Education, 19(2), pp. 237-253.

Morgan C., Hall V., \& Mackay, H. (1983). The selection of secondary school headteachers. Milton Keynes, England: Open University Press.

Morgan, W.J., Sives, A., \& Appleton, S. (2005). Managing the international recruitment of health workers and teachers: do Commonwealth agreements provide an answer? The Round Table, 94 (379), pp.225-38.

Powney, J., Wilson, V., \& Hall, S. (2003). Teachers' careers: The impact of age, disability, ethnicity, gender and sexual orientation. London: Department for Education and Skills. 
Shah, S., \& Shaikh, J. (2010). Leadership progression of Muslim male teachers: Interplay of ethnicity, faith and visibility. School Leadership \& Management, 30(1), pp.19-33

Tajfel, H. \& Turner, J. C. (1979). “An Integrative Theory of Intergroup Conflict”. In W. G. Austin \& S. Worchel (Eds.), The Social Psychology of Intergroup Relations. Monterey, CA: Brooks-Cole.

Tajfel, H. \& Turner, J. C. (1986). “The Social Identity Theory of Inter-group Behavior”. In S. Worchel \& L. W. Austin (Eds.), Psychology of Intergroup Relations. Chicago: Nelson-Hall.

Whitaker, R. (1991). Canadian immigration policy since confederation. Ottawa: Canadian Historical Association. 